\title{
OBJECT BASED IMAGE ANALYSIS TO SUPPORT ENVIRONMENTAL MONITORING UNDER THE EUROPEAN HABITAT DIRECTIVE: A CASE STUDY FROM DECOVER
}

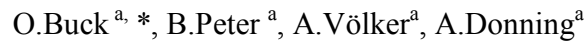 \\ ${ }^{a}$ EFTAS Remote Sensing GmbH, 48145 Münster, Germany - (oliver.buck, benedikt.peter, andreas.voelker, \\ axel.donning)@eftas.com
}

ISPRS WG I/4, III/4, IV/2, VII/2

KEY WORDS: NATURA 2000, Rapideye, data mining, OBIA, GMES

\begin{abstract}
:
DeCOVER serves as a national extension of the European Global Monitoring for Environment and Security (GMES) initiative. It was initiated to develop land cover information services adapted to German user needs. One of its three service developments pillars is the application of Remote Sensing to support environmental monitoring schemes under the European Habitats Directive.

Within two DeCOVER test sites located in North-Rhine Westphalia/Germany an object-based indicator classification approach is currently being developed to monitor heath habitats of importance under the Habitats Directive. While many previous Remote Sensing projects have focused on the discrete classification of habitat types to replace fieldwork, our approach is embedded in a strong operational context to a) focus and direct fieldwork efforts by pre-field visit assessment of habitat changes (change detection) and b) support fieldwork by contributing quality parameters and GIS-ready geometries.

Using Geoeye satellite data (VHR component) and RapidEye satellite images (Multi-temporal HR component) together with existing habitat and biotope maps (knowledge and post-classification component) an image analysis approach is realised using object-based classification routines based on data mining tools to derive training information. To extract meaningful objects of heath-, sand- and grassland from the VHR-data, training sample areas have to be assigned. Thresholds and appropriate features for describing these samples are analysed by statistical algorithms and are used in the following classification. A multi-temporal approach for the acquisition of tree habitat areas integrates two RapidEye scenes into the classification process. To validate classification accuracies and potential transects were sampled in the field and analyzed for their structural composition using top view field photos of $1 \mathrm{~m}^{2}$. First results demonstrate the realistic option to directly support the fieldwork or reduce its post-processing costs.
\end{abstract}

\section{INTRODUCTION}

\subsection{The objectives of the DeCOVER2 project}

GMES (Global Monitoring for Environment and Security) is a joint initiative of European Commission and European Space Agency. The purpose of the GMES programme is according to a recent communication from the European Commission "...to guarantee continuous access to information services on the environment and security issues which are based on permanent space-based observation and in-situ infrastructures...." (EC 2011, www.gmes.info). The programme is currently evolving from a research \& development stage to an operational phase. Until 2013, operational GMES services should be provided on a larger scale, building on and complementing current development activities (EU regulation No 911/2010).

DeCOVER serves as a national extension of the GMES initiative. It was initiated to support the GMES land cover monitoring service components and provide information adapted to German user needs at regional, national and international level using innovative remote sensing and data modelling techniques.

DeCOVER is currently in its second research phase focussing on three main objectives (Buck 2010):

\footnotetext{
* Corresponding author
}

- to support the harmonization and update of national and international land cover / land use data sets using remote sensing change detection methods

- to link this information to existing national topographic reference datasets as well as European data models

- to provide additional thematic services not covered by existing GMES services to support national and regional monitoring in the field of agriculture and environmental monitoring

\subsection{Remote Sensing and the habitat directive}

The DeCOVER thematic services for environmental monitoring are based on information requirements following the implementation of the Habitats Directive (Council Directive 92/43/EEC). This directive, together with the Birds Directive (Council Directive 79/409/EEC), are the most important instruments for European environmental protection. Sites out of both directives form the Natura 2000 network of protected sites, for which regular monitoring information on habitat conservation status are required (Art.17 of the habitat directive). The required monitoring systems according to Art.11 shall not be limited to designated and protected Natura 2000 sites, but cover the whole administrative territory. The conservation status 
of habitats has to be provided using these monitoring systems and based upon four parameters (EC 2005):

1) Area: the sum of habitat patches actually occupied by the habitat

2) Range: the region in which habitats are likely to occur

3) Specific structures and functions: typical species compositions, habitat structures and indicators

4) Future prospects: for distribution and survival of typical habitats

Several member states have established specific assessment schemes or guidelines to assess habitat structures and functions (parameter 3 above). These schemes define criteria to judge and group the quality of every habitat patch into three quality condition states:
1) Favourable
2) Unfavourable - inadequate
3) Unfavourable - bad.

The German assessment schemes follow the EU recommendation and provide more detailed guidance to rank habitat conservation status (Sachteleben \& Behrens 2010).

The assessment scheme for the habitat type "European dry heaths" (habitat code 4030) for example includes structural information on the percentage of non-vegetated ground as well as maturity stages of heath (Table 1).

\begin{tabular}{|c|c|c|c|}
\hline Criteria / Rank & A & $\mathrm{B}$ & $\mathrm{C}$ \\
\hline $\begin{array}{l}\text { Completeness of } \\
\text { typical habitat } \\
\text { structures }\end{array}$ & $\begin{array}{l}\text { excellent } \\
\text { condition }\end{array}$ & good condition & $\begin{array}{l}\text { medium-bad } \\
\text { condition }\end{array}$ \\
\hline \multirow[t]{2}{*}{$\begin{array}{l}\text { Age } \\
\text { structure/phases } \\
\text { (area \% per age } \\
\text { phase) }\end{array}$} & \multicolumn{3}{|c|}{ Pioneer, Build-up, Maturity and Degeneration phases } \\
\hline & $\begin{array}{l}\text { all four age } \\
\text { phases existent } \\
\text { and } \\
\text { degeneration } \\
\text { phase }<50 \% \\
\text { of area }\end{array}$ & $\begin{array}{l}\text { at most three } \\
\text { age phases } \\
\text { existent or } \\
\text { degeneration } \\
\text { phase } \\
\text { occupies } 50 \text { - } \\
75 \% \text { of area }\end{array}$ & $\begin{array}{l}\text { degeneration } \\
\text { phase occupies } \\
>75 \% \text { of area }\end{array}$ \\
\hline Cover of open soil & $5-10 \%$ & $<5 \%$ & missing or $>25 \%$ \\
\hline $\begin{array}{l}\text { Completeness of } \\
\text { typical habitat } \\
\text { species }\end{array}$ & existent & $\begin{array}{l}\text { to a large } \\
\text { extent existent }\end{array}$ & $\begin{array}{l}\text { only partially } \\
\text { existent }\end{array}$ \\
\hline \multicolumn{4}{|c|}{$\begin{array}{l}\text { Reference list of habitat typical species: } \\
\text { Agrostis tenuis, Calluna vulgaris, Carex ericetorum, Carex pilulifera, Cuscuta } \\
\text { epithymum, Danthonia decumbens, Deschampsia flexuosa, Empetrum nigrum, } \\
\text { Festuca ovina agg., Galium harcynicum, Genista anglica, Genista germanica, } \\
\text { Genista pilosa, Lycopodium spp., Nardus stricta, Vaccinium myrtillus, } \\
\text { Vaccinium vitis-idaea, Hypnum jutlandicum, Polytrichum juniperinum, } \\
\text { Polytrichum piliferum, Ptilidium ciliare, Cladonia spp }\end{array}$} \\
\hline Disturbances & no to little & medium & strong \\
\hline $\begin{array}{lr}\begin{array}{l}\text { Destruction of } \\
\text { vegetation and }\end{array} \\
\text { heath typical soil } \\
\text { structure (e.g. } \\
\text { through military or } \\
\text { recreational usage; } \\
\text { reason and extent of } \\
\begin{array}{l}\text { damage in \% of } \\
\text { area) }\end{array}\end{array}$ & $<5 \%$ & $5-10 \%$ & $>10 \%$ \\
\hline 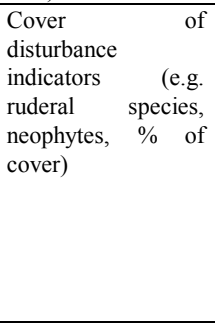 & $\begin{array}{l}\text { no invasive } \\
\text { alien species, } \\
\text { other } \\
\text { disturbance } \\
\text { indicators } \\
<5 \%\end{array}$ & $\begin{array}{l}\text { invasive alien } \\
\text { species } \\
\text { restricted to } \\
\text { punctual } \\
\text { occurrences } \\
\text { without } \\
\text { distribution } \\
\text { tendencies. } \\
\begin{array}{l}\text { Cover of } \\
\text { disturbance } \\
\text { indicator }\end{array} \\
\end{array}$ & $\begin{array}{l}\text { (wide)spread } \\
\text { occurrence of } \\
\text { invasive alien } \\
\text { species or other } \\
\text { disturbance } \\
\text { indicators } \\
(>10 \%)\end{array}$ \\
\hline
\end{tabular}

\begin{tabular}{|l|l|l|l|}
\hline & & $\begin{array}{l}\text { species (5- } \\
10 \%)\end{array}$ & \\
\hline $\begin{array}{l}\text { Cover of trees and } \\
\text { shrubs }\end{array}$ & $<10 \%$ & $10-35 \%$ & $>35-70 \%$ \\
\hline $\begin{array}{l}\text { Afforestation or } \\
\text { planted trees (area } \\
\%)\end{array}$ & 0 & $\begin{array}{l}<=5 \text { (single } \\
\text { trees) }\end{array}$ & $>5$ \\
\hline
\end{tabular}

Table 1. Assessment matrix of 4030 „Dry European heaths“ (translated and adapted after Sachteleben \& Behrens 2010)

The fact that remote sensing can be used to provide information on conservation status in support of the Art.17 habitat directive has been demonstrated by various researchers who applied satellite image derived indicators to detect habitat changes and trends (Bock et al 2005, Cantarello \& Newton 2008, Alexandridis et al 2009). Especially newly emerging very high spectral and/or spatial satellite sensors have been applied to a range of habitat types with promising results (Förster et al 2008, Frick et al 2005). New approaches are also developed to classify right down to plant species compositions using hyperspectral data (Schmidtlein \& Sassin 2004, Weiss 2008).

While many previous remote sensing projects have focused on the discrete classification of habitat types and species composition to replace fieldwork, our approach is embedded in a more operational context. This means that remote sensing shall not replace field monitoring to assess habitat patch conservation status, but provide "screening information" to guide and support field work. This is in line with the high expectations of monitoring experts to use remote sensing tools for detecting changes (Vanden Borre et al 2011). As can be seen in the heath habitat assessment scheme (Table 1) remote sensing tools can provide valuable insight into development process and existing status of selected habitat types, but additional information is generally needed to completely define the habitat conservations status.

The approach presented here is thus to apply a two-stage approach based on remote sensing information to support a) Field work planning (by focus subsequent field work on areas of likely changes), b) Fieldwork itself (by thematic information and habitat patch boundaries/geometries).

\section{DATA AND METHODS}

\subsection{Data and study sites}

This two-stage approach is currently developed within two Natura 2000 sites of regional importance in North RhineWestphalia (NRW) / Germany dominated by heath and grassland habitats. The test site "Westruper Heide" (Natura 2000 site code DE4209303) is a small heath dominated area. It is well accessible leading to high recreational pressure and managed by local and regional authorities. Management includes regular heath burning to foster regeneration and traditional grazing by sheep. The test site "Westruper Heide" was used to test our classification and validation approaches. Based on the experiences the methods will be adapted and applied to the neighbouring second test site "Truppenübungsplatz Borkenberge" in a next project step. This site is an active military training site (Natura 2000 site code DE4209304) covering around 1700 hectares. Habitats of importance are mostly heath and grassland habitats. Due to the active usage, site access is very limited and monitoring authorities have a high interest in remote sensing tools to provide objective information on site dynamics. 


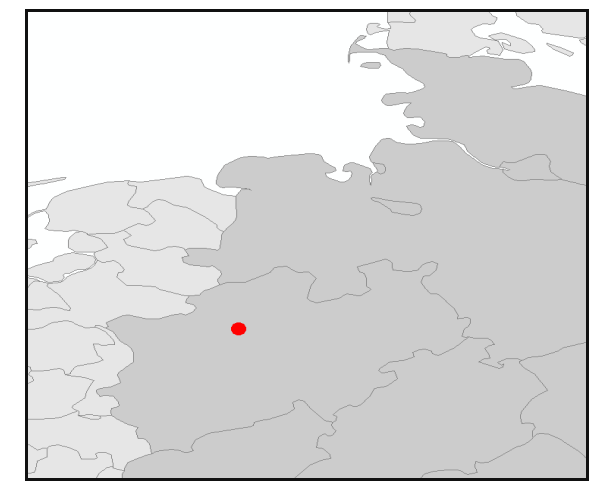

Figure 1. Location of the test sites within NRW (Germany)

\begin{tabular}{|c|c|c|c|}
\hline $\begin{array}{l}\text { satellite } \\
\text { sensor }\end{array}$ & $\begin{array}{c}\text { date of } \\
\text { acquisition }\end{array}$ & $\begin{array}{l}\text { spatial } \\
\text { resolution }\end{array}$ & spectral resolution \\
\hline GeoEye & 06.04 .2010 & 0.5 meters & $\begin{array}{l}\text { visible and near- } \\
\text { infrared }\end{array}$ \\
\hline Rapideye & $\begin{array}{c}24.05 .2009 \\
19.09 .2009 \\
18.04 .2010 \\
03.06 .2010 \\
12 / 20.08 .2010 \\
10.10 .2010\end{array}$ & 5 meters & $\begin{array}{l}\text { visible, rededge and } \\
\text { near-infrared }\end{array}$ \\
\hline
\end{tabular}

Table 2. Satellite data available for the two test sites

A very high resolution GeoEye satellite image and multitemporal high resolution RapidEye images covering both sites were available for this study (Table 2). Existing habitat and biotope maps from the responsible monitoring authorities were used to guide the visual training procedure. Although the existing habitat maps seemed outdated, they proved a valuable information source for stratifying the training samples.

\subsection{Classification Methods}

In the beginning of the project a user requirement survey was conducted to get information on existing threats and processes within the test site. During a field visit site photos, impressions and habitat structures were recorded. The consulted monitoring experts showed high expectations in a classification process to provide change and indicator information on habitat pressures and threats. The classes should thus be reproducible and be transferable to other test sites. The classification nomenclature was then set up so that the:

a) land cover classes should act as indicators to provide relevant information on conservation status of heath habitats (see Table 1),

b) land cover classes show a high potential for spectral and/or structural separability (based on expert judgment),

c) classes should be reproducible to allow future classifications and post-classification change analysis.

The following classes were then defined and discussed during another user consultation process:

- Heathland

- Sand

- Grassland

- Waterbodies

- Cryptogam dominated

- Wood/tree habitats

A multi-temporal object-based classification approach with Definiens Developer 7 (eCognition) was implemented for the detection of tree habitats, using RapidEye scenes from 24.05.2009 and 19.09.2009. The idea of such an object-based approach is to interpret the image information not in single pixels, but in more meaningful image objects (Blaschke 2010). Using a multi-scale segmentation technique image objects are extracted at different resolutions to construct a hierarchical network of image objects with known super- and sub-objects in a neighborhood context (Baatz \& Schäpe 1999).

The tree habitat classification approach is based on former developments for linear landscape element classifications on CIR aerial images (Völker \& Müterthies 2008) that were already successfully transferred to simulated RapidEye images (Völker \& Büker 2009). In a first step, a multi-resolution segmentation of the 1st image is used to split the entire area into meaningful objects, using segmentation parameters (scale parameter $=100$, shape factor $=0,5$ and compactness factor $=$ $0,8)$ which lead to more compact patterns, matching the shape of tree habitats and forest patterns in a satisfying way. Afterwards a morphological closing algorithm is used in order to clean the image objects from small border artefacts, leading to straighter border lines at the beginning of the following classification process. Using the NDVI, all areas with no vegetation in one of the two images are temporarily classified as non-Vegetation. The mean value of the two red edge channel values (from 24.05.2009 and 19.09.2009) can be used to produce a quick and transferrable multi-temporal classification feature for tree habitat areas. All vegetated areas fitting a certain threshold are classified as tree habitats. The automatic tree habitat mapping was then integrated into the following automatic heathland classification, serving as a precise mask of wooden areas.

The image segmentation for the following heathland classification was performed on the Geoeye satellite image covering both test sites. A scale parameter of 20 was regarded as most suitable to represent the real objects on the ground following a trial-and error approach using different scale factors. To limit the time-consuming segmentation process on the area of interest the official Natura 2000 site boundaries were used to restrict the classification area. To focus the classification to open non-forest habitats of interest in our study, all tree habitats were masked out prior to the classification process.

The next step is to define training areas for the subsequent classification. Because the intention of our study is to limit field work, we decided to train our seven basic land cover classes by on-screen selection of homogenous areas. For each class about ten training segments were selected. To determine suitable thresholds for the subsequent fuzzy logic classification multiple image feature values are calculated for all of these training areas and exported in a text file for further analysis. The file is imported into the data mining software See5/C5.0. This decision tree software partitions training samples into homogeneous subsets and suggests branch nodes and best fitting features to separate the classes. The decision trees and feature values thresholds suggested by See5/C5.0 were then used to setup and perform the fuzzy logic classification within Definiens Developer.

\subsection{Field sampling and validation methods}

The coverage (in \%) of specific habitat species and structures is an important aspects to assess heath habitat conservation status. It is thus very important to know, how sensitive the 
classification approach is to changing land cover fractions. To gain information on this aspects and to validate our classification on test site 1 (Westruper Heide) we established three initial field sampling transects. Each sampling transects is comprised of $1 \times 1 \mathrm{~m}$ aligned squares with a minimum transect length of $50 \mathrm{~m}$ (Fig. 2). We considered $50 \mathrm{~m}$ to be a suitable value whereas the statistical reliability of the chosen sample size has still to be tested. The exact transect locations were chosen in a way that the method could be tested on homogenous and inhomogeneous areas. For this purpose the first transects were placed by visual impression of the surveyor.

For each sample-square one top view photo was taken. For each top view photo groundcover fractions (in \%) were later defined on-screen using a GIS. The single fractions were partly estimated (using a regular grid on top of the photo, Fig. 3) and partly calculated by digitizing the classes and calculating areas using the GIS. For the validation we chose only sample squares which fell completely into a single classified polygon. The following groundcover classes were used:

- A: Dead leafs and litter (new class included during the sampling due to rich abundance)

- B: Cryptogams (e.g. mosses of the genus Hypnum, Polytrichum and the invasive species Campylopus introflexus; few species of lichens, mainly Cladonia)

- C: Grassland

- D: Heath land (Calluna vulgaris)

- E: Bare sand

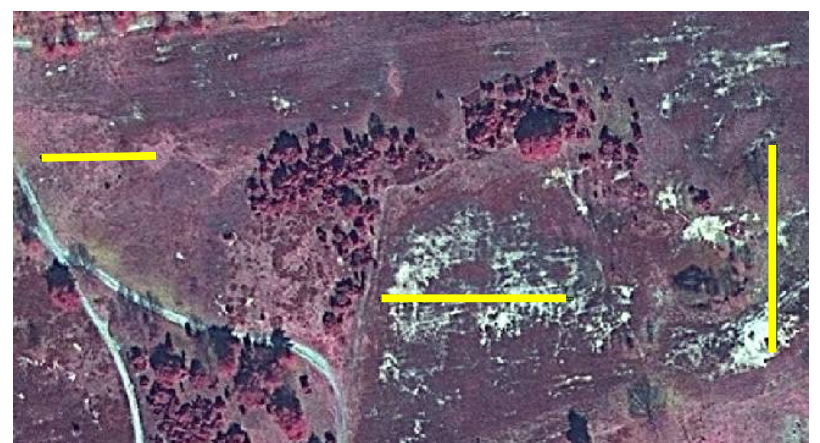

Figure 2. Location of the first three sample transects in the test site „Westruper Heide“

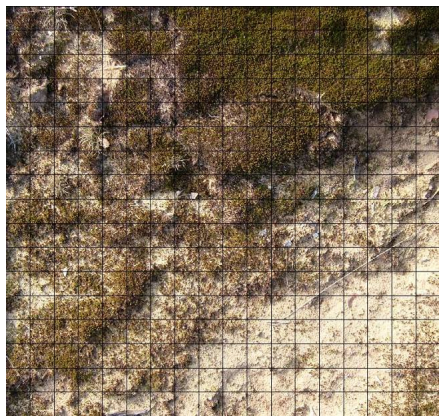

Figure 3. Example top view photo $(1 \times 1 \mathrm{~m})$ taken as a ground sample within the transects including overlaid GIS interpretation grid

\section{RESULTS}

\subsection{Classification results}

The classification output for the test site Westruper Heide shows the distribution pattern of the land cover classes under investigation (Figure 4). Due to the early Geoeye acquisition date in April, deciduous single trees in the test site were not easy to distinguish and shadows were included as a separate cover class. Apart from the North-eastern part heath habitat patches appeared compact, with only little dispersed open sand patches. Management activities (fire burning in 2009) resulted in a distinct habitat patch dominated by cryptogam in the southwest and east of the test site.

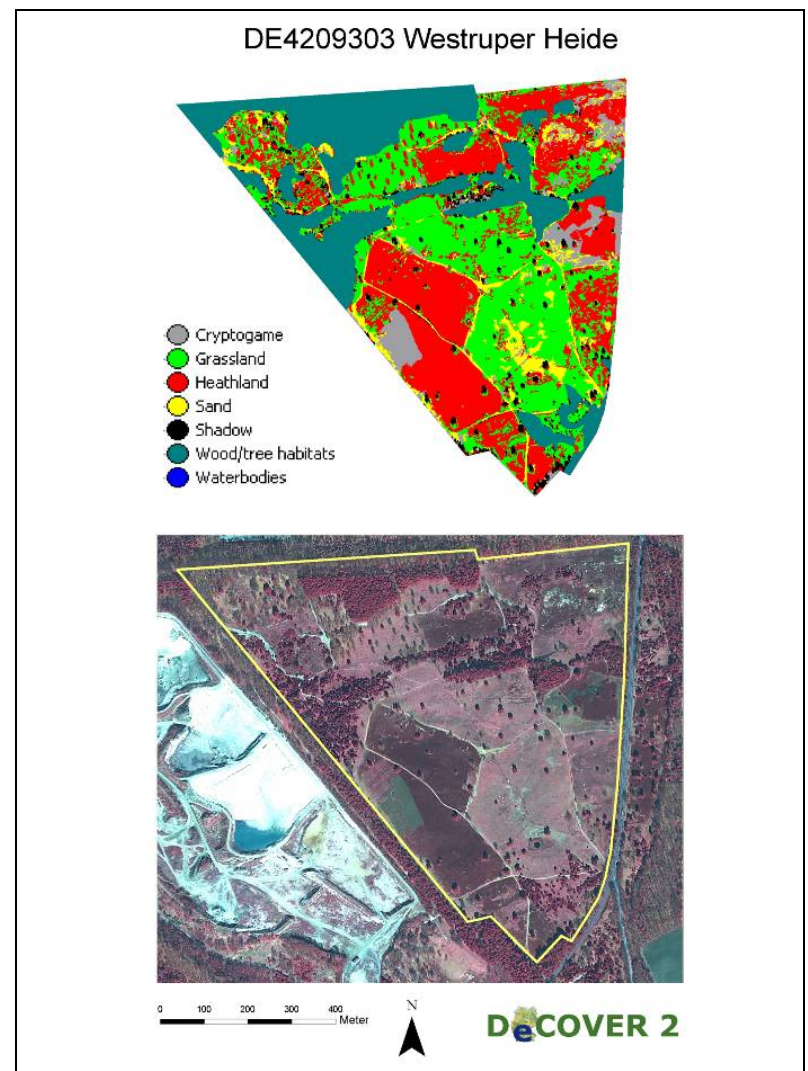

Figure 4. Classification result (top) and Geoeye image (43-2 channel combination) for the test site Westruper Heide

In order to validate the first results of the dry heath classification in the Westruper Heide test site, a stratified random control sample of 100 points with at least 10 points within each class was conducted. The reference points were interpreted by a manual on-screen expert classification. Onscreen accuracy assessment was included to proof the objective that our defined classes can be trained and validated using image information only, and thus limit field training efforts prior to classification. The validation results showed an overall accuracy of $68,0 \%$ with a kappa coefficient of 0,563 . With a producer's accuracy of $92 \%$ (Table 3 ), almost all heath areas were detected, but the user's accuracy of $70 \%$ shows, that too many areas were incorrectly classified as heath. The user accuracy of $97 \%$ shows that the grassland classification is mostly correct, but with a producer accuracy of $63 \%$ not adequately complete. Sand and cryptogams display poor classification accuracies.

\begin{tabular}{llllll} 
Class & $\begin{array}{l}\text { Reference } \\
\text { totals }\end{array}$ & $\begin{array}{l}\text { Classified } \\
\text { Totals }\end{array}$ & $\begin{array}{l}\text { Number } \\
\text { correct }\end{array}$ & $\begin{array}{l}\text { Producer } \\
\text { accuracy }\end{array}$ & $\begin{array}{l}\text { User } \\
\text { accuracy }\end{array}$ \\
\hline Heath & 25 & 33 & 23 & $92,0 \%$ & $69,7 \%$ \\
Grassland & 49 & 32 & 31 & $63,3 \%$ & $96,9 \%$ \\
Shadow & 15 & 10 & 9 & $60,0 \%$ & $90,0 \%$ \\
Sand & 2 & 13 & 1 & $50,0 \%$ & $7,7 \%$
\end{tabular}


$\begin{array}{llllll}\text { Cryptogam } & 9 & 12 & 4 & 44,4 \% & 33,3 \%\end{array}$

Table 3. On-screen accuracy Assessment of the Westruper Heide test site

\subsection{Field validation results}

The on-screen accuracy assessment results were mostly confirmed by our field transect validation. The following results have to be considered as first results. The field sampling method was mainly invented to gain information on classification potential per land cover class, i.e. on which classes the classification worked already with acceptable outputs and on which classes further improvements have to be made, before the classification method is transferred to the hardly accessible test site 2 "Truppenübungsplatz Borkenberge".

\begin{tabular}{|c|c|c|c|c|c|}
\hline Class & $\begin{array}{c}\text { Total } \\
\text { number of } \\
\text { sample } \\
\text { squares } \\
\text { within the } \\
\text { transects as } \\
\text { classified by } \\
\text { e-cognition }\end{array}$ & $\begin{array}{c}\text { True } \\
\text { number of } \\
\text { sample } \\
\text { squares } \\
\text { within the } \\
\text { transects } \\
\text { dominated } \\
\text { by the class }\end{array}$ & $\begin{array}{c}\text { Most } \\
\text { abundant } \\
\text { true class } \\
\text { in the } \\
\text { field } \\
\text { sample }\end{array}$ & $\begin{array}{c}\text { Range of } \\
\text { abundance: } \\
\text { number of } \\
\text { squares }\end{array}$ & $\begin{array}{c}\text { Validation of } \\
\text { Ground } \\
\text { Truth }\end{array}$ \\
\hline $\begin{array}{c}\text { A } \\
\text { Dead } \\
\text { leaves and } \\
\text { litter } \\
\end{array}$ & - & - & - & - & $\begin{array}{l}\text { New Class } \\
\text { invented after } \\
\text { field sampling }\end{array}$ \\
\hline $\begin{array}{c}\mathbf{B} \\
\text { Cryptogam } \\
\end{array}$ & 36 & 7 & A & - & $\begin{array}{c}\text { Mixed up with } \\
\text { Class A }\end{array}$ \\
\hline $\begin{array}{c}\mathbf{C} \\
\text { Grassland } \\
\end{array}$ & - & - & - & - & $\begin{array}{c}\text { Portion too } \\
\text { small }\end{array}$ \\
\hline \multirow{4}{*}{$\begin{array}{c}\text { D } \\
\text { Heathland }\end{array}$} & \multirow{4}{*}{29} & \multirow{4}{*}{18} & \multirow{4}{*}{ D } & $<10 \%: 6$ & \multirow{4}{*}{$\begin{array}{l}\text { to be } \\
\text { improved by a } \\
\text { better tuning } \\
\text { of the } \\
\text { classification } \\
\text { process }\end{array}$} \\
\hline & & & & $10-30 \%: 2$ & \\
\hline & & & & $>30 \%-50 \%: 6$ & \\
\hline & & & & $>50 \%: 15$ & \\
\hline \multirow{4}{*}{$\begin{array}{c}\mathbf{E} \\
\text { Bare sand }\end{array}$} & \multirow{4}{*}{31} & \multirow{4}{*}{15} & \multirow{4}{*}{ E } & $<10 \%: 5$ & \multirow{4}{*}{$\begin{array}{c}\text { to be } \\
\text { improved by a } \\
\text { better tuning } \\
\text { of the } \\
\text { classification } \\
\text { process }\end{array}$} \\
\hline & & & & $10-30 \%: 6$ & \\
\hline & & & & $>30 \%-50 \%: 8$ & \\
\hline & & & & $>50 \%: 12$ & \\
\hline
\end{tabular}

Table 4. Summary results of field transect validation

As can be seen from the results (Table 4) heath was best classified, with most squares having $>50 \%$ of heath coverage. But even squares with an abundance of less than $10 \%$ heath were also classified as heath. Comparable results were obtained for the class Bare Sand. Unfortunately grassland samples were not collected during the field visit. Squares dominated by cryptogams were poorly detected and often confused with the dead leaves and litter class.

\section{DISCUSSION AND CONCLUSION}

The first test of the sampling methods as described in this text took place in the test site 1 "Westruper Heide". The validation results showed the classification potential for "heath" and "grassland", and indicated areas for improvement for "cryptogam", "bare sand", as well as the importance of image acquisition date to take into account new classes such as "shadows" and "Dead leaves and litter". Especially for the later class it showed the clear drawback of applying an automated classification method with minimized field training efforts. Taking field samples close to the image acquisition date would have included this class in the classification and improved results.

The first test showed clearly the problems of applying relatively broad class definitions and their spatial representation as polygons. This is a strong simplification of the very fine existing spatial land cover patterns. Despite the small sample squares of $1 \mathrm{~m}^{2}$ almost never was a sample squares covered by a single land cover class. In summary it must be said that:

- the applied classes in our object-based automatic classification approach reflect the dominating true class in the best case for heath and grassland habitat

- using true ground data is essential to improve classification and define new classes or class combinations (in this case the classes "Cryptogams" and "Dead leaves and litter")

- Some classes need ground data for better calibration. For example the class "Bare sand" includes squares with a relatively low true proportion of bare sand.

- The true class "Cryptogams" (= dominated by cryptogams) gained from the fieldwork was very poorly detected by the automatic classification. Improvement is expected by integration the "Dead leaves and litter" class.

In the next step we will modify the field sampling methods in consideration of the results from the "Westruper Heide" to be applied and repeated in our second test site "Truppenübungsplatz Borkenberge". In detail the following steps are planned for this field sample campaign:

- Definition of sample classes for gaining training areas for the automatic classification

- Definition of sample sizes (covering all classes of interest) for validation purpose with help of back round information

- Planning of additional methods for sample taking (using much bigger squares within the transects or using very big squares replacing the transects) for testing different methods against each other

- Increasing the sample sizes (at least 100 squares for each abundant class)

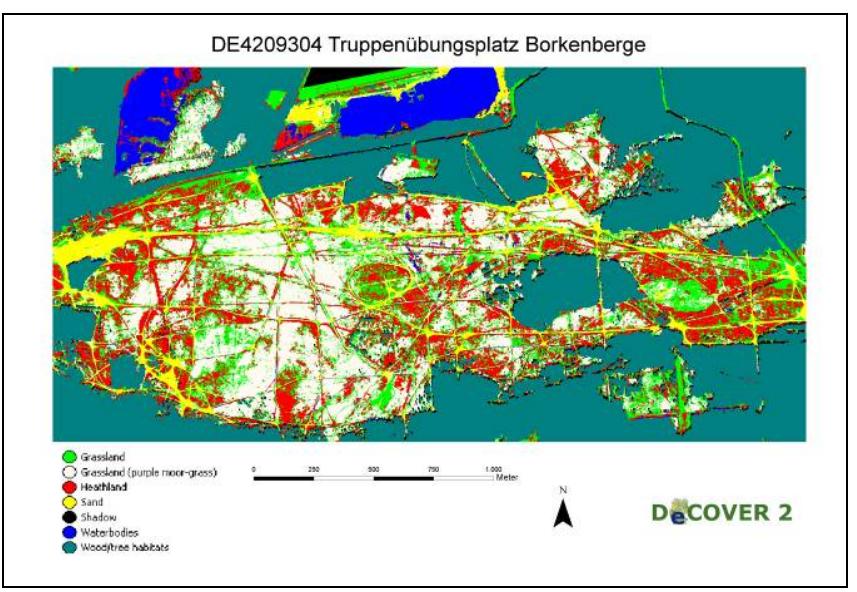

Figure 5. First classification output from the test site 2

A first classification for test site 2 has been performed, but not validated yet, using the same object-based approach. This classification will be used to assist field sampling planning and was used to discuss focal points with the local monitoring authorities (Fig. 5). The initial classification outputs show compared to test site1 more complex distribution patterns of heath, open soil structures (caused by the active military usage, sand roads/paths), dispersed temporary water pools and 
widespread occurrence of grass habitats, with dominating patches of purple moor grass (Molinia caerulea). Improved field sampling is planned for the beginning of May 2011. An improved classification will then be performed using the experience from test site 1 based on a combination of Worldview-2 data and RapidEye data from 2011 (image tasking in progress).

Following the described classification process a change detection approach based on the comparison of the classification of two time steps will be developed in the next project stage in order to provide change information to the management and coordination of habitat monitoring tasks. For change detection methods object-based classification results are shown to deliver better results than per-pixel approaches (Im et al. 2008). However, the abundance analysis of the land cover patterns highlights the need to consider the very fine details of surface composition also in the change detection context.

Examining the main aims of the described study, it can be summarized, that the $1^{\text {st }}$ aim to support fieldwork with qualitative (thematic) and quantitative (geometric), GIS-ready information is accessible. However, improvements are still necessary in order to fulfil the $2^{\text {nd }}$ aim, to assist fieldwork planning with means of change detection by focussing on special areas of interest.

\section{REFERENCES}

Alexandridis T.K., Lazaridou E., Tsirika A., Zalidis G.C. 2009. Using Earth Observation to update a Natura 2000 habitat. Journal of Environmental Management 90, pp.2243-2251.

Baatz, M. \& Schäpe, A. 1999: Object-oriented and multi-scale image analysis in semantic net-works. Proceedings of the 2nd International Symposium on Operationalization of Remote Sensing, Enschede, ITC, August 16-20, 1999.

Blaschke, T. 2010. Object based image analysis for remote sensing. ISPRS Journal of Photogrammetry and Remote Sensing, 65/1, pp. 2-16.

Bock, M., Xofis, P., Rossner, G., Wissen, M., \& Mitchley, J. 2005. Object oriented methods for habitat mapping in multiple scales: Case studies from Northern Germany and North Downs GB. Journal for Nature Conservation 13, pp. 75-89.

Buck, O. 2010. DeCOVER 2 - The German GMES extension to support land cover data systems: Status and outlook. Proceedings ESA Living Planet Symposium Bergen, Norway. 28.06-02.07.2010. ESA Special Publication SP-686 on CDROM.

Cantarello, E., \& Newton, A.C. 2008. Identifying cost-effective indicators to assess the conservation status of forested habitats in Natura 2000 sites. Forest Ecology and Management 256, pp. 815-826.

EC 2005. Note to the Habitats Committee. Assessment, monitoring and reporting of conservation status - Preparing the 2001-2007 report under Article 17 of the Habitats Directive (DocHab-04-03/03 rev.3). European Commission. Brussels.
EC 2011. COM (2011)152 Towards a space strategy for the European Union that benefits its citizens. Communication from the Commission to the Council, the European Parliament, the European economic and social committee of the regions. European Commission. Date of Issue 04.03.2011. European Commission. Brussels.

Frick, A., Weyer, G., Kenneweg, H.; Kleinschmitt, B. 2005. A Knowledge-based approach to vegetation monitoring with Quickbird imagery. In: ISPRS Workshop 2005 - HighResolution Earth Imaging for Geospatial Information, May 1720, 2005, Hannover.

Im, J.; Jensen, J. R. \& Tullis, J. A. 2008: Object-based change detection using correlation image analysis and image segmentation. International Journal of Remote Sensing, 29/2, pp. 399-423.

Sachteleben, J. and M. Behrens. 2010. Konzept zum Monitoring des Erhaltungszustandes von Lebensraumtypen und Arten der FFH-Richtlinie in Deutschland. -Ergebnisse des F+EVorhabens "Konzeptionelle Umsetzung der EU-Vorgaben zum FFH-Monitoring und Berichtspflichten in Deutschland". - BfNSkripten 278, 183 pages, Federal Agency for Nature Conservation. Bonn. Germany.

Schmidtlein, S. and Sassin, J. 2004. Mapping of continuous floristic gradients in grasslands using hyperspectral imagery. Remote Sensing of Environment 92, pp.126-138.

Vanden Borre J, Paelinckx D, Mücher CA, Kooistra L, Haest B, De Blust G, Schmidt AM 2011. Integrating remote sensing in Natura 2000 habitat monitoring: Prospects on the way forward. Journal for Nature Conservation 19 (2), pp. 116-125.

Völker, A. \& Büker, C. 2009: RapidEye - Das „schnelle Auge“ für das Monitoring von Cross-ComplianceLandschaftselementen? Eine Potentialanalyse mit simulierten Satellitendaten. In: Seyfert, E. (Ed.): Publikationen der Deutschen Gesellschaft für Photogrammetrie, Fernerkundung und Geoinformation, Band 18. Potsdam, pp. 101-110.

Völker, A. \& Müterthies, A. 2008: Landschaftsökologische Modellierung und automatisierte Erfassung von Landschaftselementen für das Monitoring und die Bewertung einer nachhal-tigen Kulturlandschaft. In: Seyfert, E. (Ed.): Publikationen der Deutschen Gesellschaft für Photogrammetrie, Fernerkundung und Geoinformation, Band 17. Potsdam, pp. 161-170.

\section{ACKNOWLEDGEMENT}

The DeCOVER 2 project is funded by the Federal Ministry of Economics and Technology (BMWi) via the German Aerospace Center (DLR): FKZ 50EE0908, 50EE0909, 50EE0910, 50EE0911, 50EE0912, 50EE0913, 50EE0914, 50EE0915. 